\title{
Release Sites and Calcium Channels in Hair Cells of the Chick's Cochlea
}

\author{
C. Martinez-Dunst, ${ }^{1}$ R. L. Michaels, ${ }^{1}$ and P. A. Fuchs ${ }^{2}$ \\ ${ }^{1}$ Department of Physiology, University of Colorado Health Sciences Center, Denver, Colorado 80262, and 2The Center for \\ Hearing Sciences, Department of Otolaryngology, Head and Neck Surgery, Johns Hopkins University School of Medicine, \\ Baltimore, Maryland 21205-2195
}

Rapid transmitter release at synapses depends on the close proximity of voltage-gated calcium channels (VGCCs). In mechanosensory hair cells of the vertebrate inner ear, dihydropyridine-sensitive VGCCs may be preferentially expressed at release sites to support transmitter release. In support of this hypothesis we have found that whole-cell current through VGCCs covaried with afferent innervation density among hair cells of the chick's basilar papilla (the avian analog of the mammalian Organ of Corti). The size as well as number of presynaptic dense bodies (PDBs) around which transmitter vesicles cluster varied systematically among equivalent populations of hair cells examined with electron microscopy. The total number of VGCCs was correlated with total release area (PDB cross-sectional area $\times$ the number of PDBs) among neurally located (tall) hair cells. Abneural, short hair cells with little or no afferent contact expressed a low number of VGCCs independent of release area. The implication is that hair cells augment calcium channel expression by adding release sites and by making release sites larger. This suggests further that aspects of hair cell excitability, such as electrical tuning, could depend on the synaptic architecture of each cell.

Key words: voltage-gated calcium channels; active zones; presynaptic terminals; presynaptic dense bodies; high-voltage electron microscopy; whole-cell voltage clamp; 3-D reconstruction
Mechanosensory hair cells of vertebrates form chemical synapses with associated afferent dendrites. Voltage-gated calcium channels (VGCCs) in the basolateral membrane of the hair cell open with depolarization, causing transmitter release that can drive phase-locking in postsynaptic afferent fibers at rates up to $5 \mathrm{kHz}$. Rapid transmitter release at other synapses is ensured by the close localization of VGCCs at release sites (Adler et al., 1991), as visualized with labeled VGCC toxins (Robitaille et al., 1990; Cohen et al., 1991). VGCCs may be localized at release sites in hair cells as well. Loose patch recording and calcium imaging suggest that VGCCs occur in "hotspots" or clusters in the basolateral membrane of the hair cell (Roberts et al., 1990; Tucker and Fettiplace, 1995), possibly corresponding to transmitter release sites (Issa and Hudspeth, 1994). A numerical agreement between the predicted number of calcium and potassium channels and large intramembranous particles at release sites strengthened the suggestion that hair cell VGCCs may be expressed exclusively in synaptic clusters (Roberts et al., 1990).

VGCCs also participate in the electrical tuning of hair cells by activating large-conductance, calcium-activated potassium chan-

Received July 3, 1997; revised Sept. 9, 1997; accepted Sept. 16, 1997.

This work was supported in part by research Grant 7 RO1 DC 00276 from the National Institute on Deafness and Other Communication Disorders (NIDCD) and National Institutes of Health biotechnology resources Grant RR00592 to the Boulder Laboratory for 3-Dimensional Fine Structure. R.L.M. was the recipient of a Reentry Supplement Award from NIDCD. We thank Steve Fadul for help with image analysis, Mark Dunst and Greg Michaels for graphics consults, and Jim Kremer and the staff at the HVEM facility in Boulder for their help with all aspects of high-voltage microscopy and 3-D reconstruction and modeling. We also thank Kent Fagan and the late Marjorie Alders for their contributions to early experiments and David Ryugo for reading an earlier draft of this paper.

C.M.-D. and R.L.M. contributed equally to this work

Correspondence should be addressed to P. A. Fuchs, The Center for Hearing Sciences, 521 Traylor Building, The Johns Hopkins University School of Medicine, 720 Rutland Avenue, Baltimore, MD 21205-2195.

Copyright (C) 1997 Society for Neuroscience $0270-6474 / 97 / 179133-12 \$ 05.00 / 0$ nels (Lewis and Hudspeth, 1983; Art and Fettiplace, 1987; Fuchs and Evans, 1988; Fuchs et al., 1988). There is substantial evidence that a single functionally homogeneous class of dihydropyridinesensitive VGCCs is responsible for both transmitter release and electrical tuning in hair cells (Art and Fettiplace, 1987; Hudspeth and Lewis, 1988; Fuchs et al., 1990; Roberts et al., 1990; Zidanic and Fuchs, 1995). Intriguingly, VGCC number increases systematically with the resonant frequency of electrically tuned hair cells in the turtle (Art et al., 1993), and there is evidence that the number of transmitter release sites per hair cell also rises along the tonotopic axis (Sneary, 1988). If VGCC expression depends on the synaptic architecture of the cell, then tonotopic variations in channel number could arise from underlying variations in the afferent innervation of the cochlea.

We have tested this hypothesis in the basilar papilla of the chick, where the pattern of distribution of afferent fibers has been well described (Hirokawa, 1978; Tanaka and Smith, 1978; Fischer, 1992). Afferent fibers contact tall hair cells on the neural edge of the basilar papilla, whereas short hair cells on the abneural edge receive caliciform efferent synapses. This pattern breaks down near the low-frequency apex where efferent fibers are infrequent and the afferent innervation spreads across the entire papilla (Fischer, 1992; Zidanic and Fuchs, 1996). Small efferent boutons also are found among neural tall hair cells throughout the papilla (Zidanic and Fuchs, 1996). We have measured barium currents through VGCCs and counted release sites in tall neural (inner) and short abneural (outer) hair cells in three locations along the apical half of the basilar papilla, spanning regions in which the afferent innervation density varies significantly. The hypothesis predicts that calcium channel and release site number should be greatest in tall, neural hair cells, but lower in short, abneural hair cells. This proposition has been found to be qualitatively correct, but quantitative divergence from its simplest 
form has revealed additional features of calcium channel expression in hair cells.

\section{MATERIALS AND METHODS}

Profiles of presynaptic dense body (PDB) structure and distribution using conventional electron microscopy. Cochleas from six chickens (2-5 weeks posthatch) were rapidly dissected, fixed in $0.1 \mathrm{M}$ phosphate buffer with $2 \%$ paraformaldehyde and $2 \%$ glutaraldehyde, and then post-fixed in $1 \%$ osmium tetroxide in phosphate buffer. During dehydration in graded alcohols, tissue was stained en bloc with $10 \mathrm{~mm}$ uranyl acetate in $95 \%$ ethanol and then embedded in Eponate 12 (Ted Pella, Inc., Redding, CA). Between 18 and 22 ultrathin sections, spaced a minimum of $250 \mathrm{~nm}$ apart and each containing the entire cochlear profile in cross section, were collected on Formvar-coated slot grids $(0.4 \%$ Formvar in ethylene dichloride) at locations centered $0.3,1.0$, and $2.0 \mathrm{~mm}$ from the apical tip of the papilla (see Fig. $1 B$ ). Sections were stained with uranyl acetate and lead citrate and then viewed on a Phillips CM-10 electron microscope at an accelerating voltage of $80 \mathrm{kV}$. Photographic montages of each cross section were used to map PDB distribution as a function of distance from the neural edge of the cochlea.

High-voltage electron microscopy and computer reconstruction of hair cells. Thick serial sections $(0.5 \mu \mathrm{m})$ were collected from $0.3,1.0$, and 2.0 $\mathrm{mm}$ regions of a subset of the cochleas used for thin section microscopy. Sections were collected on Formvar-coated slot grids (0.7\% Formvar in ethylene dichloride), stained with lead citrate and uranyl acetate, carboncoated on both sides, and then viewed and photographed on a highvoltage electron microscope (HVEM Facility, Boulder, CO) operating at $1 \mathrm{MeV}$. Digitized images from HVEM negatives were collected on a VAX computer and then transferred to a Silicon Graphics R4000XZ workstation. Tomographic data derived from these images were viewed and analyzed using the MIDAS program (for alignment and orientation of sections) followed by the IMOD model rendering program (copyright 1994; Boulder Laboratory for 3-Dimensional Fine Structure, University of Colorado, Boulder, CO) (Kremer et al., 1996). Three-dimensional (3-D) wire models were further manipulated and refined using the SYNU software package (San Diego Microscopy and Imaging Resource, San Diego, CA).

Dissection and isolation of hair cells. Neural ("tall") and abneural ("short") hair cells were isolated from three regions of the chick's cochlea: $0.3,1.0$, and $2.0 \mathrm{~mm}$ from the apical tip of the basilar papilla. Chicks (2-5 weeks posthatch) were decapitated, and the head was bisected along the sagittal midline. After removal of skin, a scalpel was used to cut tangentially and posteriorly through the external ear canal, revealing the tympanum. The tympanum and columella were removed, and the cochlear duct was pulled free through the enlarged oval window. This "external" removal of the cochlear duct is rapid $(<5$ min after decapitation) and tears off the underlying cochlear ganglion, providing better visualization of the neural(tall hair cell) edge of the basilar papilla.

The cochlear duct was immersed in low calcium ("dissociation") saline containing $0.1 \mathrm{mg} / \mathrm{ml}$ protease (Type XXIV, Sigma, St. Louis, MO.) for $10 \mathrm{~min}$ at room temperature. During this time the tegmentum vasculosum was dissected away. The tectorial membrane was peeled off with a fine tungsten needle. The cochlear duct was rinsed in protease-free saline and transferred to DMEM (with $38 \mathrm{mM} \mathrm{NaHCO}_{3}$ and $13 \mathrm{mM} \mathrm{HEPES}$ buffer) at $37^{\circ} \mathrm{C}$ in a $\mathrm{CO}_{2}$ incubator, where it remained for at least $1 \mathrm{hr}$ before selection of hair cells. Repeated isolates were taken over the course of 4-6 hr; the cochlea were returned to the incubator between times.

Hair cells were isolated from selected regions of the basilar papilla under a Wild dissecting microscope. Regions of epithelium ranging 200-400 $\mu \mathrm{m}$ ("0.3 mm region"), 900-1100 $\mu \mathrm{m}$ ("1 $\mathrm{mm}$ region"), and $1900-2100 \mu \mathrm{m}$ ("2 $\mathrm{mm}$ region") from the apical tip of the papilla (measured using a calibrated ocular micrometer) were marked off by transverse cuts with a sharpened tungsten probe (see Fig. 1B). A transfer pipette with tip opening of $\sim 30 \mu \mathrm{m}$ was used to aspirate hair cells from the neural or abneural third $(\sim 130 \mu \mathrm{m})$ of each one of these regions. Thus data were compiled for six groups of cells: neural and abneural hair cells from each of the $0.3,1.0$, and $2.0 \mathrm{~mm}$ regions. Isolated cells were placed in saline on the stage of an inverted compound microscope (Nikon Diaphot) and viewed at $400 \times$. The length of the cell body (from base of the hair bundle to the synaptic pole of the cell) and width of the apical surface were recorded for each cell using an ocular micrometer with a resolution of $\sim 0.3 \mu \mathrm{m}$.

Whole-cell calcium-current measurements. Whole-cell, tight-seal recordings of calcium current were made from isolated cells. Inward currents were recorded from cells in which all outward currents were blocked by substitution of internal potassium with cesium. Inward currents were enhanced by using external barium rather than calcium as the current carrier. Recordings were made with $3 \mathrm{M} \Omega$ electrodes (pulled from $100 \mu \mathrm{l}$ borosilicate micropipettes; Drummond Scientific, Broomall, PA). These were coated with cross country ski wax (purple) to reduce capacitance and were filled with (in $\mathrm{mm}$ ): $\mathrm{CsCl} 130, \mathrm{KCl} 5, \mathrm{MgCl}_{2} 2$, $\mathrm{CaCl}_{2}$ 0.1, EGTA 11, HEPES 10, CsOH 25, pH 7.3, 280 mOsM. In addition, $5 \mathrm{mM} \mathrm{Na}_{2} \mathrm{ATP}$ was added on the day of use. Patch rupture was achieved by pulsed suction and monitored by the increase in capacitive and outward current during a voltage step from -60 to $0 \mathrm{mV}$ (Axopatch 1D, Axon Instruments, Foster City, CA).

A rapid perfusion array was used to apply control and experimental saline to the cells. The array consisted of a set of glass capillaries, each $\sim 0.2 \mathrm{~mm}$ in diameter, located $0.5 \mathrm{~mm}$ from the cell. Gravity feed through these capillaries was regulated with manual stopcocks. Control "chick saline" contained (in $\mathrm{mM}$ ): $\mathrm{NaCl} 154, \mathrm{KCl} 6, \mathrm{MgCl}_{2} 2.3, \mathrm{CaCl}_{2}$ 5.6, HEPES 5, glucose 8, pH 7.4, 298 mOsM. Calcium channel current was enhanced using external barium as the charge carrier (in mM): $\mathrm{NaCl} 121$, $\mathrm{KCl} 6, \mathrm{MgCl}_{2} 1, \mathrm{BaCl}_{2}$ 20, HEPES 10, $\mathrm{pH} 7.4,305$ mOsM.

$I-V$ curves were collected based on 100 msec voltage steps from -100 to $+90 \mathrm{mV}$ in $10 \mathrm{mV}$ increments. The holding voltage was $-60 \mathrm{mV}$. Peak steady-state barium current was found at -10 to $10 \mathrm{mV}$. The leak (slope) conductance was measured between -60 and $-100 \mathrm{mV}$, and post hoc subtraction of leak current was made arithmetically assuming a linear leak throughout the current-voltage relation. (The combination of internal cesium and external barium served to block all voltage and calciumgated potassium channels in the cells.) All recordings were made at room temperature $\left(22-24^{\circ} \mathrm{C}\right)$. The junction potential of $-3 \mathrm{mV}$ was not incorporated into the membrane potentials given here. Peak barium currents were determined within 1-2 min of establishing the whole-cell recording to minimize rundown of calcium channels (e.g., $86 \pm 36 \mathrm{sec}$; mean $\pm \mathrm{SD}$ elapsed time; 44 recordings in cells from the $2 \mathrm{~mm}$ region).

\section{RESULTS}

\section{Distribution of PDBs in hair cells}

This study examined the relationship between calcium channel number and transmitter release sites in hair cells, taking advantage of the selective innervation of the chick's basilar papilla by afferent fibers (Hirokawa, 1978; Tanaka and Smith, 1978; Fischer, 1992). Afferents preferentially contact tall (inner) hair cells on the neural margin of the papilla, especially in the basal (high frequency) half (Fischer, 1992). We have determined the disposition of PDBs (present at release sites) in neural and abneural hair cells at three positions along the length of the basilar papilla (Fig. 1 $A, B$ ). These were 200- $\mu \mathrm{m}$-long segments centered 0.3, 1.0, and $2.0 \mathrm{~mm}$ from the apical tip of the basilar papilla.

As in other tonically releasing cells, such as photoreceptors, release sites in hair cells are marked by a PDB around which transmitter vesicles cluster (Fig. $1 C, D$ ). These PDBs were easily counted in electron micrographs of chick hair cells. Nonserial cross sections were used to construct montage maps of PDB distribution in each of the three regions (Fig. 2, top). A qualitative appreciation of the variations in release site distribution was immediately obvious from inspection of these maps. PDB number fell as one moved from neural to abneural hair cells across the cochlear width. Furthermore, this differential distribution was exaggerated in more basal positions.

Semi-randomized thin sections provided a qualitative view of the distribution of PDBs in cochlear hair cells. A quantitative mapping of PDBs on a per cell basis was accomplished using HVEM of $0.5-\mu \mathrm{m}$-thick serial cross sections of the basilar papilla and 3-D computer reconstructions of digitized images. We were able to reconstruct entire hair cells in 15-30 serial sections, significantly less than would have been required by conventional thin section electron micrograph. PDB diameters were $<250 \mathrm{~nm}$ (see below) and therefore were usually captured entirely within individual sections, which simplified the counting procedure. Tall 


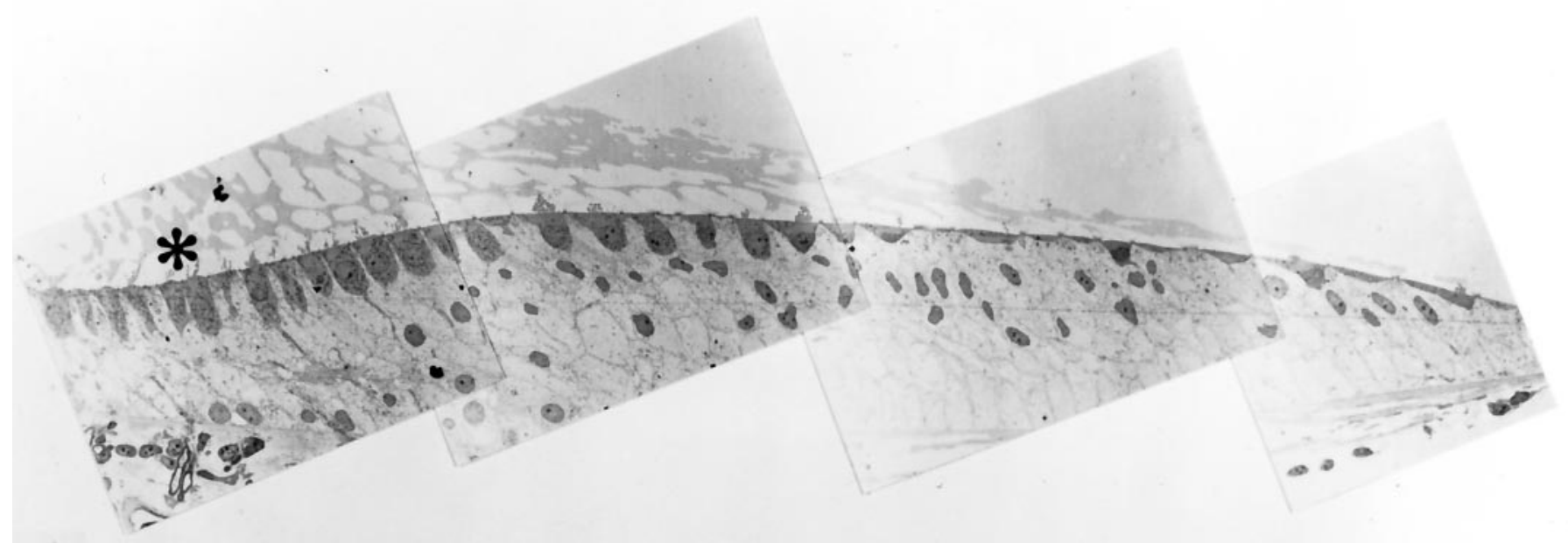

A
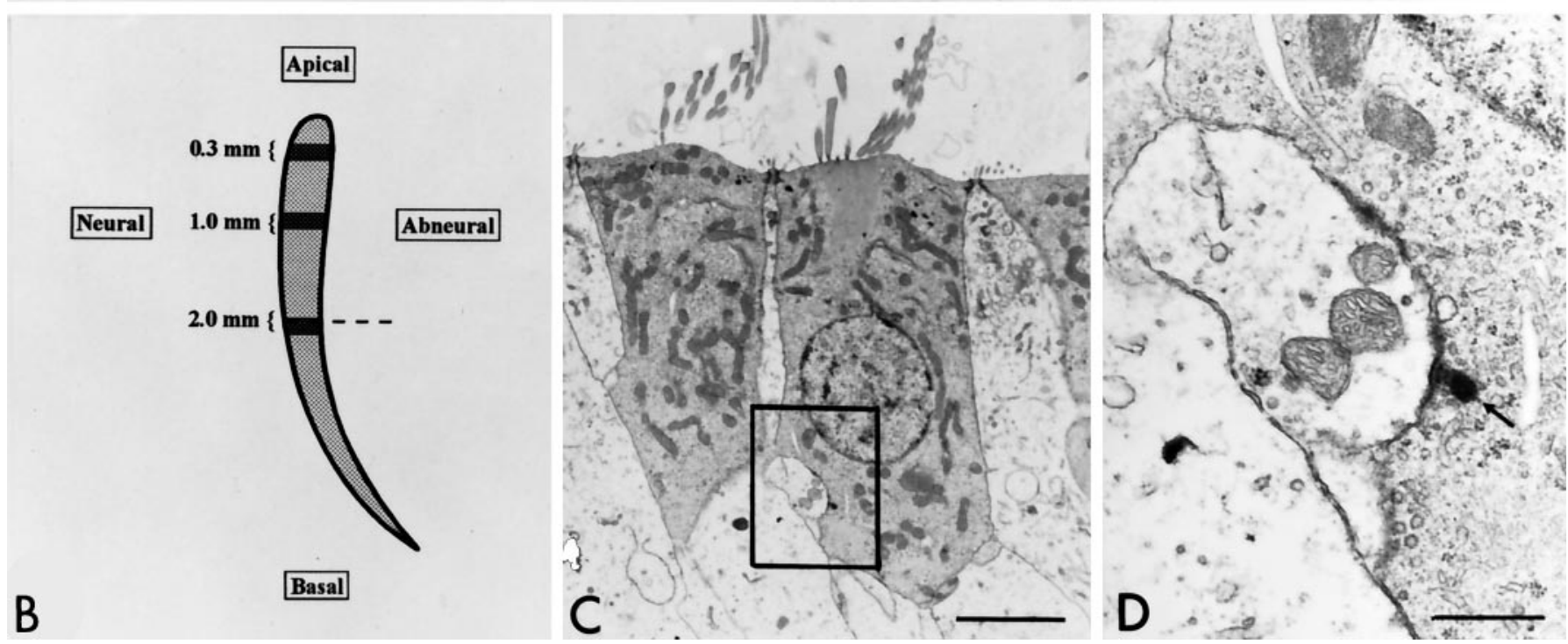

Figure 1. Mapping of release sites in the basilar papilla. $A$, Thin section electron micrographic montage from the $2 \mathrm{~mm}$ region of the basilar papilla. Hair cells are characteristically darker than are supporting cells. The asterisk is positioned at the apical surface of two neural (tall) hair cells that are viewed at higher magnification in $C$ and $D$. Scale bar, $57 \mu \mathrm{m}$. B. Schematic representation of the chick basilar papilla. The three regions in which cells were studied are highlighted and labeled. Dashed line through the $2 \mathrm{~mm}$ zone indicates the approximate location and orientation of the montage in $A$. $C$, Neuronal hair cells from the $2 \mathrm{~mm}$ zone (indicated by the asterisk in $A$ ) were photographically enlarged. An afferent synapse with a PDB is identified in the box. Scale bar, $3.6 \mu \mathrm{m}$. $D$, PDB (arrow) and afferent terminal in $2 \mathrm{~mm}$ neural hair cell featured in $C$. Scale bar, $0.7 \mu \mathrm{m}$.

(inner) hair cells were taken from the neural $30 \%$ of each cross section. Short (outer) hair cells were taken from the abneural $30 \%$. Two such reconstructions of hair cells from thick sections are shown in Figure 3, where the cell and its nucleus are outlined and the PDBs are shown as bright solid dots. These two cells provide examples of several general features. First, the tall (neural) cells had more PDBs than did the short (abneural) cells in all three regions. Second, most PDBs were found below the nucleus, as seen here. Finally, the PDBs tended to be polarized to one side of a neural cell.

Complete serial reconstructions were made of 5-12 hair cells in the neural and abneural thirds from each of the three regions of interest. Total PDBs were recorded for each cell, and the mean number of PDBs per cell is shown in Figure 4. There was an average of 15 PDBs per (tall) hair cell in all three neural regions, over a range of $6-24$ at $0.3 \mathrm{~mm}, 7-25$ at $1.0 \mathrm{~mm}$, and $8-22$ at 2.0 $\mathrm{mm}$. In contrast, the mean number of PDBs per cell was lower in all abneural groups, and it fell systematically from an average of 10.9 in apical-most to less than one per cell in basal-most regions. Thus, as suggested by the afferent innervation pattern, it was found that neural (inner) hair cells consistently had more PDBs (release sites) than did abneural hair cells. This conclusion from a limited number of reconstructions corresponds to the pattern seen when a much larger number of hair cells $(\sim 40$ in each cross section) was sampled in 58 thin section montages collected from six different cochleas (Fig. 2).

During examination of these micrographs it was found that PDB size as well as number varied regionally within the basilar papilla. PDBs in apical hair cells were thinner than those found in more basal sections. Examples of PDBs from a $0.3 \mathrm{~mm}$ cell $(A)$ and a $2 \mathrm{~mm}$ cell $(B)$ are shown in Figure 5.

The widest diameter in a plane parallel to the plasma membrane (i.e., the projection of the PDB onto the active zone) was measured for approximately $100 \mathrm{PDBs}$ at each position along the 

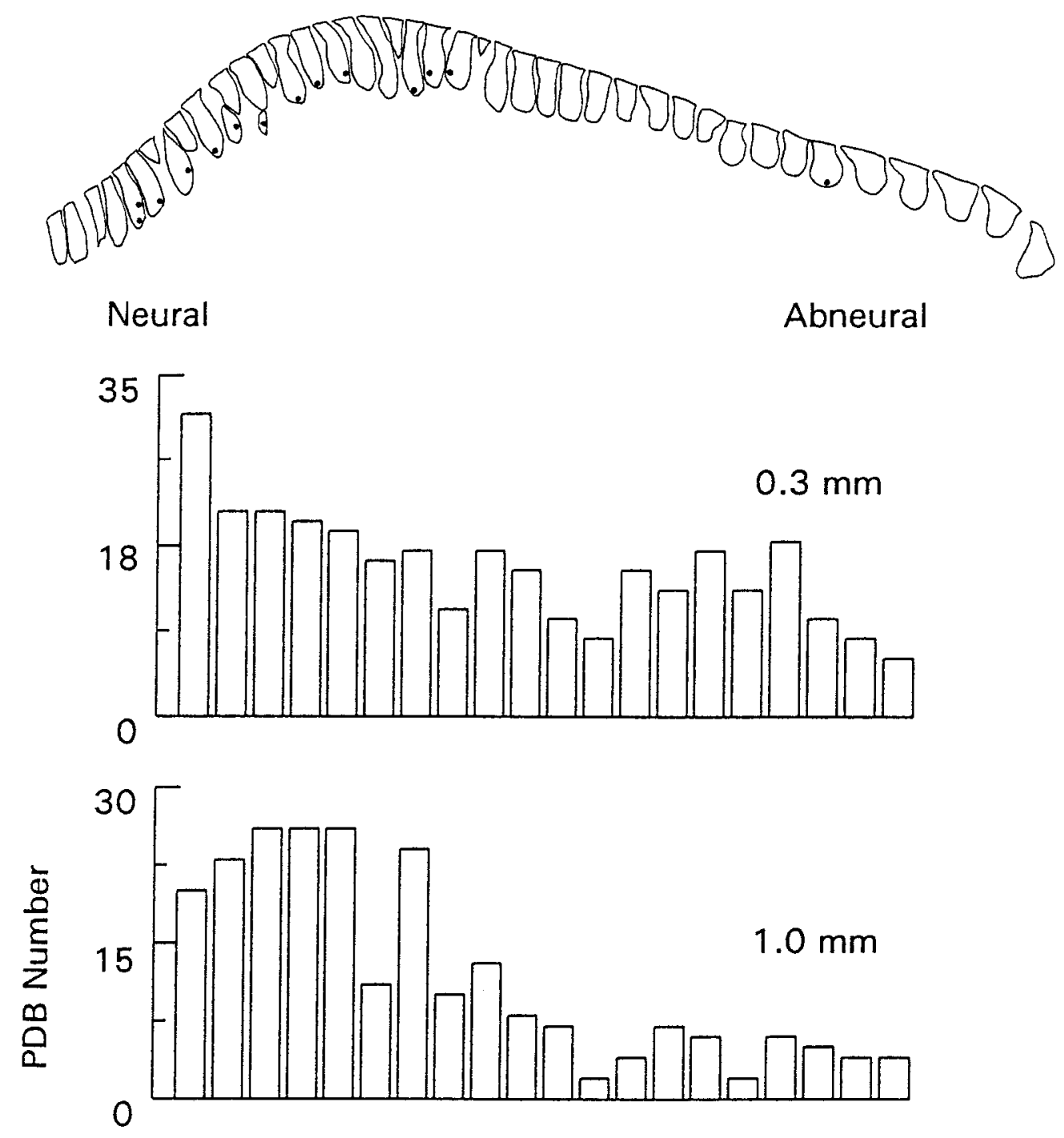

Figure 2. Presynaptic dense body $(P D B)$ distribution across the width of the basilar papilla. Nonserial thin sections $(70-90 \mathrm{~nm})$ were used to construct cross-sectional montages at each of three cochlear positions. The histograms represent number and location of PDBs (as measured from the neural edge of the papilla) counted in 18 montages at $0.3 \mathrm{~mm}, 18$ montages at $1.0 \mathrm{~mm}$, and 22 montages at $2.0 \mathrm{~mm}$ from the apex. Tracing of a representative montage from the $1.0 \mathrm{~mm}$ region is included for reference (top of figure: PDBs are shown as black dots and are not drawn to scale). PDBs were concentrated toward the neural edge of the papilla.

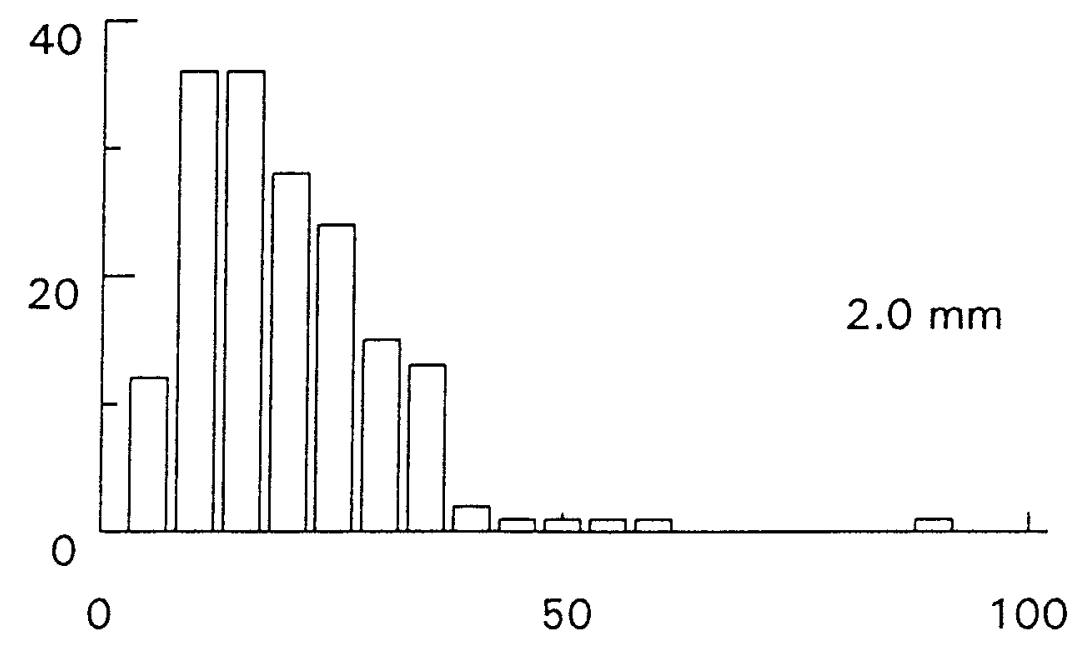

cochlear length. Mean PDB diameters for all six pools of cells are shown in Figure 6. Measurements in tall hair cells revealed average diameters (at the widest point) of 116, 163, and $211 \mathrm{~nm}$ for $100 \mathrm{PDBs}$ at each position: $0.3,1.0$, and $2.0 \mathrm{~mm}$, respectively. PDB diameter did not differ between neural and abneural (tall and short) hair cell groups at any cochlear latitude, although only very few release sites (seven) could be found in abneural hair cells at $2.0 \mathrm{~mm}$. These measurements of the widest diameter of PDBs were made in $0.5-\mu \mathrm{m}$-thick sections on the HVEM. Measurements of PDB diameter near the point of contact with plasma membrane revealed similar relationships, although here the diameter was $\sim 75 \%$ of that at the widest point (data not shown). 

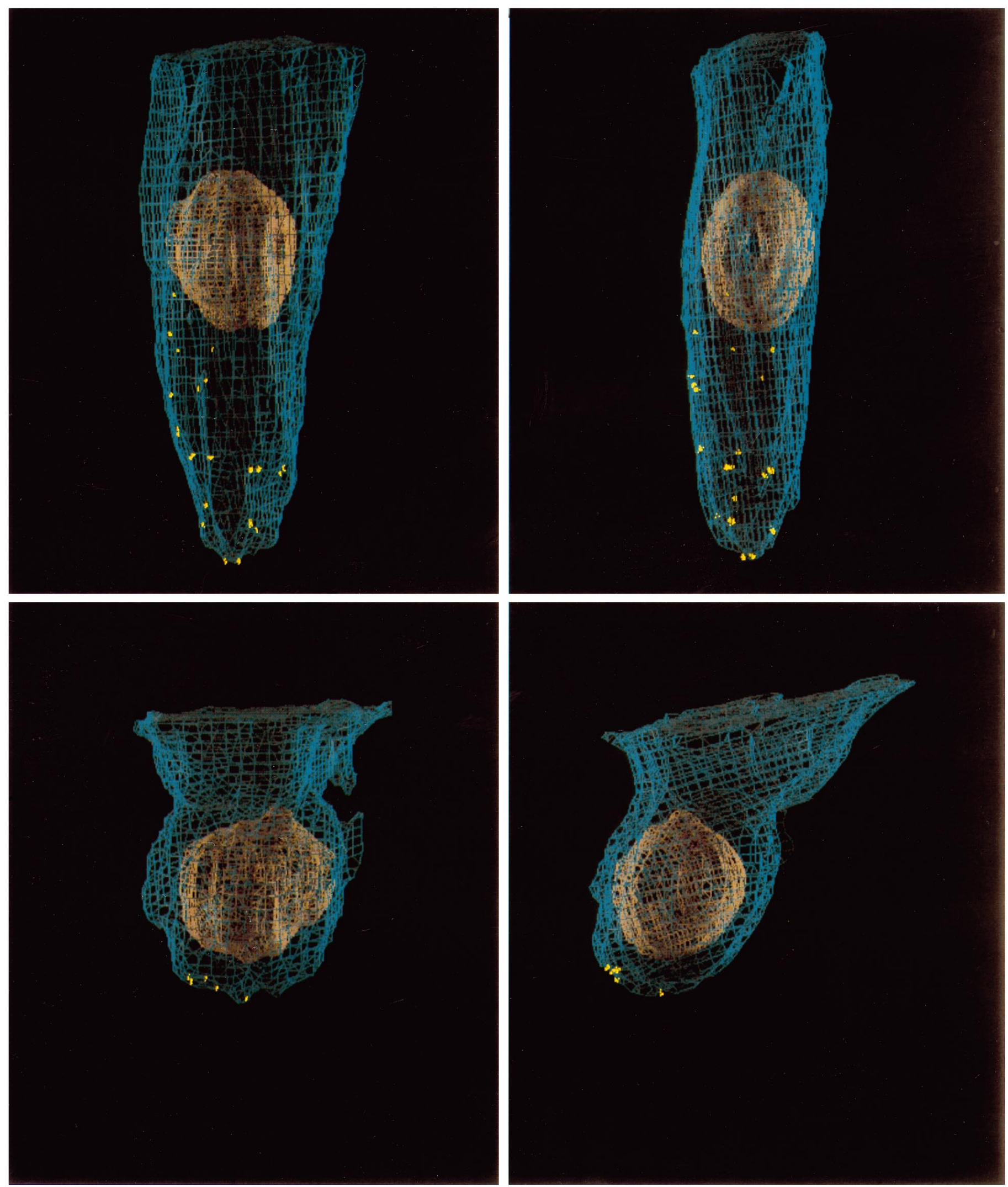

Figure 3. 3-D reconstructions of hair cells using serial thick sections $(0.5 \mu \mathrm{m})$ and HVEM. Three objects are included in these models: the cell perimeter (blue), nucleus (tan), and PDBs ( yellow). Top two panels represent a front (left panel) and side (right panel) view of a tall hair cell from the $1.0 \mathrm{~mm}$ region. The bottom two panels give similar views of a short hair cell also from the $1.0 \mathrm{~mm}$ region. PDBs were more numerous in tall neural hair cells. 


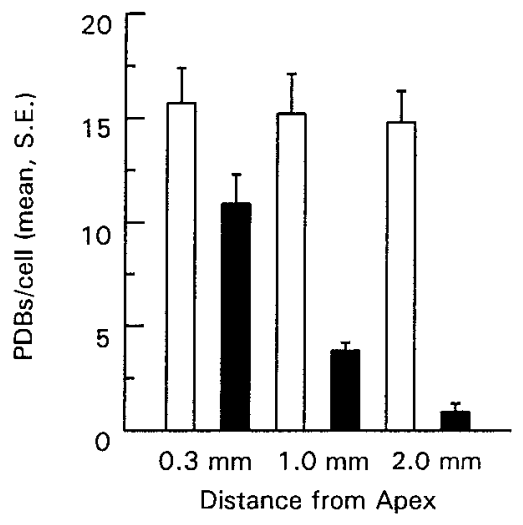

Figure 4. Average number of PDBs in neural and abneural cells in three regions of the cochlea. Total reconstructions performed for 12, 12, 9, 5, 10, and 8 cells in each group (proceeding from left to right across figure). Mean values $( \pm$ SE) from cells in the neural-most $30 \%$ of the cross section represented by open bars; cells from the abneural-most $30 \%$ represented by filled bars. All means were significantly different $(p<0.05$; Student's $t$ test) except for comparisons among neural cells.

\section{Barium currents in neural and abneural hair cells}

Tall (inner) and short (outer) hair cells were isolated by microdissection from the neural and abneural third of the papilla, respectively, at each cochlear position. This microdissection method consistently provided physiologically distinct populations of cells, as will be shown below. The reliability of this procedure also was supported by the observation that hair cells isolated from the six regions of the papilla differed morphologically. Abneural hair cells were shorter and had wider cuticular surfaces than did neural hair cells in all three locations (Table 1). The differences between neural and abneural cells were more pronounced in the more basal regions, as observed in previous studies (Murrow, 1994). The location of microdissected regions was confirmed by subsequent serial section light microscopy in one cochlea, which showed that hair cells were missing from the predicted locations.

Whole-cell recordings from exemplar neural (tall) and abneural (short) hair cells are shown in Figure 7. Immediately on rupture into whole-cell mode, depolarizing voltage commands elicited outward currents (positive-going currents in Fig. 7A,B) from most hair cells until $\mathrm{Cs}^{+}$ions infiltrated to block the $\mathrm{K}^{+}$channels. Neural tall hair cells usually produced some combination of delayed rectifier $\left(I_{\mathrm{Kv}}\right)$ and calcium-activated $\mathrm{K}^{+}$current $\left(I_{\mathrm{K}(\mathrm{Ca})}\right)$, distinguished by their different activation kinetics (Fig. 7A) (also see Fuchs et al., 1988; Fuchs and Evans, 1990). In contrast, abneural short hair cells, especially from the 1 and $2 \mathrm{~mm}$ regions, produced a rapidly inactivating or "A-type" current $\left(I_{\mathrm{Ka}}\right)$ as well as a calcium-activated $I_{\mathrm{K}(\mathrm{Ca})}$ current (Fig. $7 B$ ), as expected from the known distributions of these channel types among chick hair cells (Murrow and Fuchs, 1990; Murrow, 1994).

Within 10-30 sec of patch rupture the outward currents were eliminated by cesium in the recording pipette. In some cells this procedure directly revealed an inward current flowing through VGCCs, although in many cells these were very small. Furthermore, neural (tall) cells from the 0.3 and $1.0 \mathrm{~mm}$ regions often developed large leak currents as $\mathrm{Cs}^{+}$perfused the cytoplasm. This leak may have been caused by inward rectifier channels found in these cells (Fuchs and Evans, 1990; Murrow, 1994). Superfusion with $20 \mathrm{~mm}$ external barium saline had the twofold benefit of producing enhanced current flow through VGCCs and blocking the leak (inward rectifier) currents.
As described earlier (Fuchs et al., 1990; Zidanic and Fuchs, 1995), barium current through VGCCs was rapidly activating and noninactivating (negative-going currents in Fig. $7 A, B$ ). The barium current peaked between -10 and $+10 \mathrm{mV}$ and reversed near $+50 \mathrm{mV}$ (Fig. 7C,D). The maximum steady-state barium current in each cell (usually at $0 \mathrm{mV}$ ) was corrected for leak conductance measured between -100 and $-60 \mathrm{mV}$ (indicated by dotted lines on $I-V$ curves in Fig. $7 C, D$ ). The average leak conductance among all cells was $373 \mathrm{pS}( \pm 22 \mathrm{SE})$ and did not vary systematically between hair cells from different regions. Also there was no correlation between leak conductance and the magnitude of barium current. The peak steady-state barium current varied between 7 and 329 pA among all 166 cells in this study. A double Gaussian distribution fitted to the overall histogram had two peaks centered at 70 and $205 \mathrm{pA}$ (Fig. $8 A$ ), suggesting that two classes of hair cells could be defined with respect to barium current magnitude.

Barium current amplitude was highly correlated with the cochlear location of each cell. The mean peak barium current for each pool of cells from different regions is shown in Figure $8 B$. Neural (inner) hair cells had larger barium currents than did abneural (outer) hair cells in all three regions. As for synaptic structure, the largest difference was found in the most basal position. Two other features of these distributions are evident. There was no difference in mean barium current levels ( $\sim 50 \mathrm{pA})$ among abneural hair cells from all three regions. In contrast, the average peak barium current was smallest in the apical-most neural cells (124 pA) and largest in the basal-most neural cells (184 pA).

One explanation for these observations is simply that "tall" neural hair cells have a larger surface area than do "short" abneural hair cells, and therefore more calcium channels distributed uniformly about their surface. However, examination of the average dimensions of these cells shown in Table 1 reveals that this explanation does not suffice. Abneural hair cells are stouter as well as shorter than neural hair cells. Thus, as suggested by earlier capacitance measurements (Fuchs et al., 1988; Zidanic and Fuchs, 1995), the surface areas of tall and short hair cells do not differ substantially. Abneural hair cell membrane area is only $12 \%$ less than that of corresponding neural cells in the $0.3 \mathrm{~mm}$ region, and abneural cells at 1 and $2 \mathrm{~mm}$ have larger surface areas than do the neural hair cells at those positions. In fact, the hair cell group with the smallest surface area is actually the neural (tall) cell pool from the $2 \mathrm{~mm}$ region, and these have the largest barium currents (Fig. 8B).

These observations on cell size also apply to a consideration of "rundown" of calcium current in hair cells (Ohmori, 1984). Although this issue was not studied systematically here, previous work showed that barium currents in hair cells could be stable for several minutes, during which complete reversibility to channel blockers could be demonstrated (Fuchs et al., 1990; Zidanic and Fuchs, 1995). Virtually all the present data were collected within 2 min of beginning whole-cell recording (see Materials and Methods). If rundown did occur, it would be expected to affect the smallest cells more severely, but as noted above, these would be the neural hair cells from the $2 \mathrm{~mm}$ region, which had the largest average barium currents. Also, an analysis of current amplitude as a function of time after whole-cell break-in was made for abneural hair cells from the $2 \mathrm{~mm}$ region. These had the smallest average barium currents and so might be most likely to show rundown effects if such were significant. No correlation was found between current amplitude and elapsed time in whole-cell record- 

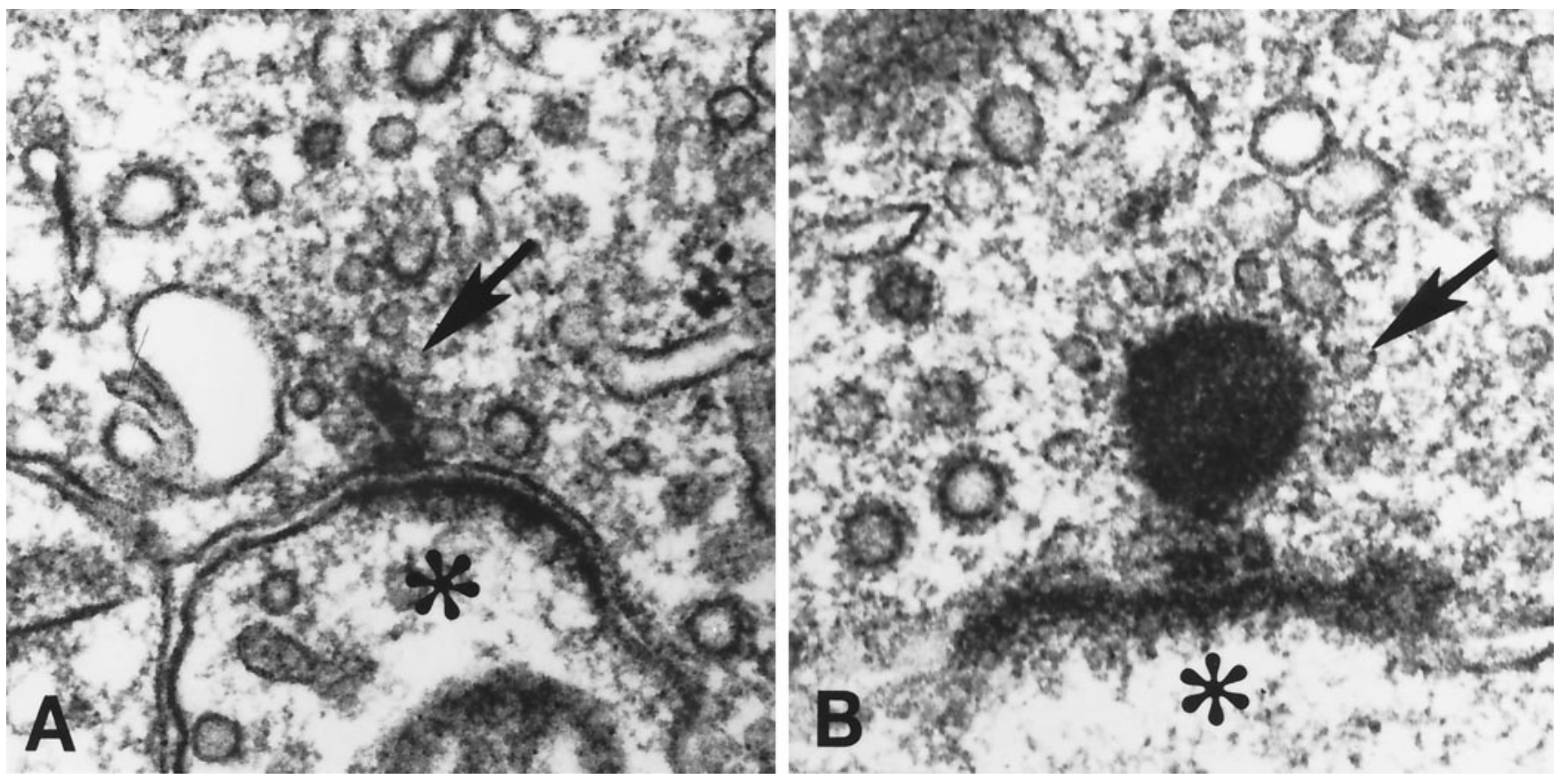

Figure 5. Representative PDBs in thin section electron micrographs of the $(A)$ apical-most $(0.3 \mathrm{~mm})$ and $(B)$ basal-most $(2.0 \mathrm{~mm})$ regions of the papilla. PDBs are surrounded by small, clear vesicles (arrows). Magnification $=107,000 \times$.

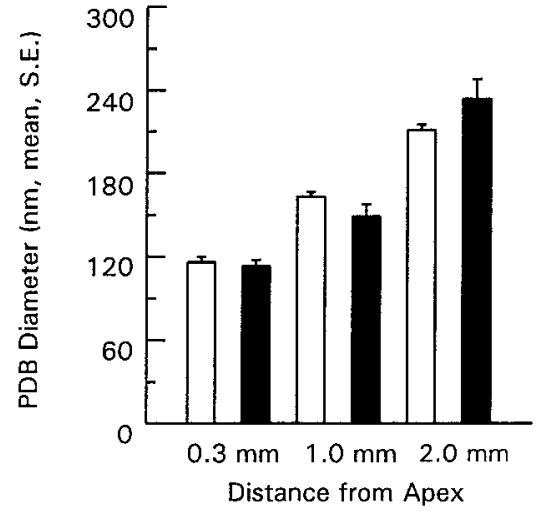

Figure 6. PDB diameter in neural (open bars) and abneural ( filled bars) cells of the three cochlear locations (mean $\pm \mathrm{SE}$ ). Each group included measurements from 100 PDBs (measured at their widest diameter) with the exception of the $1 \mathrm{~mm}(16 \mathrm{PDBs})$ and $2 \mathrm{~mm}$ (7 PDBs) abneural regions. Neural and abneural mean values were not significantly different at $0.3,1.0$, and $2.0 \mathrm{~mm}$ positions ( $p<0.5$; Student's $t$ test). PDB diameter is larger in more basal hair cells.

ing for intervals of 40-160 sec. A similar analysis of elapsed time and current amplitude for neural cells from the $2 \mathrm{~mm}$ region (spanning 44-197 sec) also showed no correlation.

\section{Correlation of barium current and release sites}

We now consider whether measurements of barium current through VGCCs support the hypothesis that calcium channels are expressed exclusively at transmitter release sites. The distribution of PDBs is summarized in Figure 9. Both PDB number and size were found to vary systematically as a function of hair cell type and position. Short abneural hair cells always had fewer PDBs and less barium current than did tall neural hair cells. However, it is clear from consideration of Figures 4 and 8 that PDB (release site) number alone was not a predictor of calcium channel number among these hair cells (Fig. 10A). For example, current levels
Table 1. Dimensions of isolated hair cells

\begin{tabular}{llll} 
& $\begin{array}{l}\text { Length }(\mu \mathrm{m}) \\
\text { mean } \pm \mathrm{SE}\end{array}$ & $\begin{array}{l}\text { Width }(\mu \mathrm{m}) \\
\text { mean } \pm \mathrm{SE}\end{array}$ & $\begin{array}{l}\text { Surface area } \\
\left(\mu \mathrm{m}^{2}\right)\end{array}$ \\
\hline 0.3 neural & $17 \pm 0.4$ & $10 \pm 0.3$ & 612 \\
0.3 abneural & $13 \pm 0.4$ & $11 \pm 0.5$ & 544 \\
1.0 neural & $16 \pm 0.4$ & $10 \pm 0.3$ & 581 \\
1.0 abneural & $10 \pm 0.2$ & $14 \pm 0.4$ & 594 \\
2.0 neural & $12 \pm 0.3$ & $9 \pm 0.3$ & 402 \\
2.0 abneural & $9 \pm 0.3$ & $14 \pm 0.5$ & 550
\end{tabular}

The mean dimensions of hair cells isolated from neural and abneural thirds of the basilar papilla at positions $0.3,1.0$, and $2.0 \mathrm{~mm}$ from the apical tip (see Fig. 1). Isolated hair cells were measured with an ocular micrometer before whole-cell recording. The length was measured from the base of the hair bundle (cuticular plate) to the synaptic pole of the cell. Width is the diameter of the cuticular surface of the cell. Neural hair cells were taller and narrower than abneural hair cells at each position, and those differences were greatest at the basal-most position. Surface area is calculated on the basis of a single-ended cylinder with those dimensions. A single-ended cylinder was chosen to approximate the effect of tapering of the cell body from cuticular plate to synaptic pole.

were equivalent in all three groups of abneural hair cells, among which PDB numbers varied 10-fold. Also, peak current varied significantly among neural hair cells, although all three groups had the same average number of PDBs.

Instead, it proved necessary to consider PDB size as well as number for this correlation, because PDB diameter also varied systematically along the cochlear length (Fig. 6). Thus, the total release area of each cell type was computed as the product of the average number of PDBs per cell and the mean cross-sectional area of the PDBs at their widest point, parallel to the plasma membrane. Thus the total release area corresponds to that area of cell membrane lying immediately under PDBs. This area of membrane might be expected to contain the VGCCs, as suggested by examination of release sites in frog saccular hair cells (Roberts et al., 1990). The resulting mean release area ranged from $0.037 \mu \mathrm{m}^{2}$ in abneural (short) cells at $0.3 \mathrm{~mm}$ to $0.52 \mu \mathrm{m}^{2}$ 

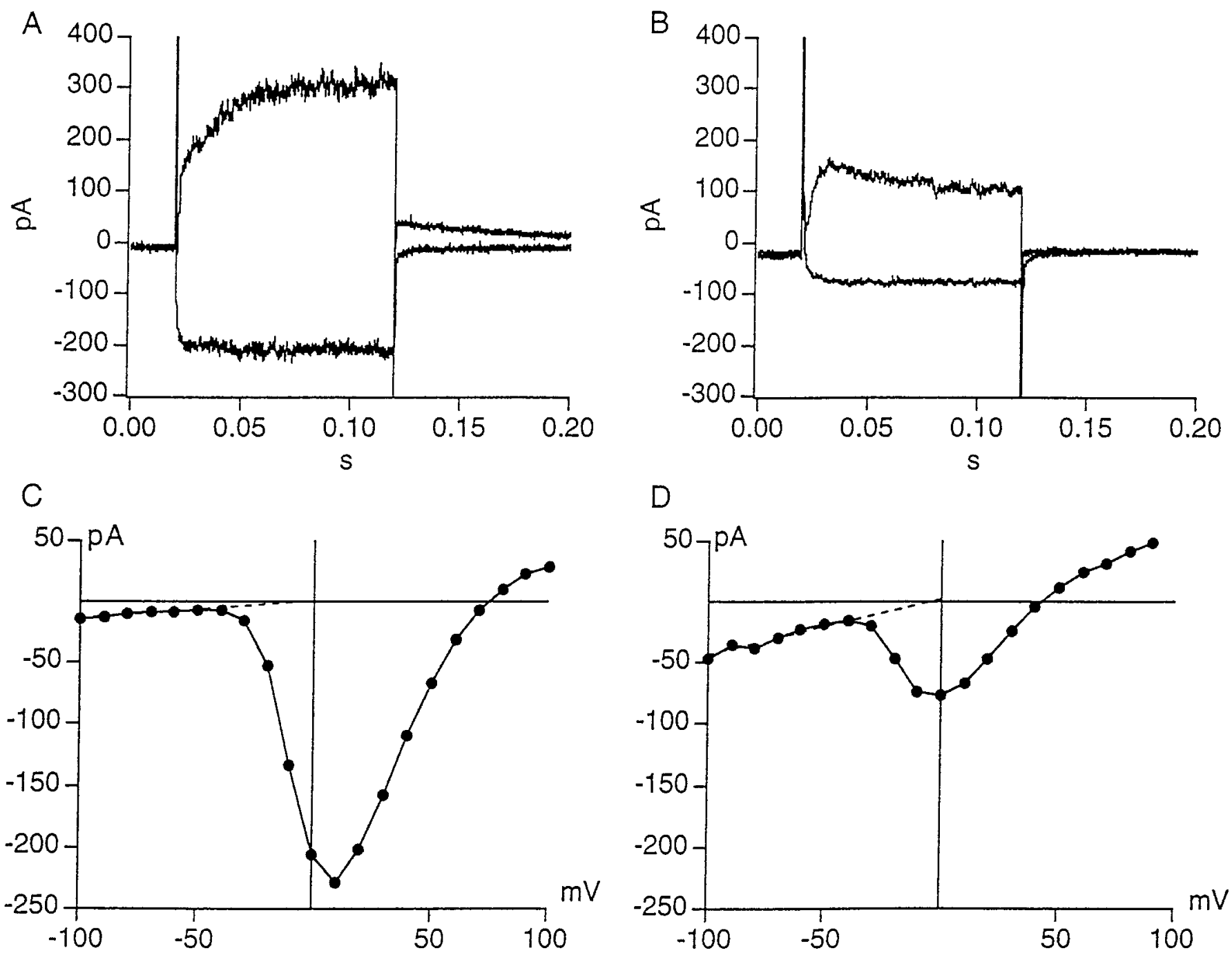

Figure 7. Exemplar whole-cell voltage-clamp recordings from $(A)$ a neural tall cell $(17 \mu \mathrm{m}$ long and $11 \mu \mathrm{m}$ wide $)$ and $(B)$ an abneural short cell $(10$ $\mu \mathrm{m}$ long and $12 \mu \mathrm{m}$ wide) from the $1 \mathrm{~mm}$ region. In each panel the outward currents (upward-going) were produced by a voltage step to $0 \mathrm{mV}$ immediately on breaking into the whole-cell mode. The inward currents (downward-going) were recorded 1-2 min later, after internal cesium blocked potassium channels, and in the presence of $20 \mathrm{~mm}$ external barium. $C, D$, The barium current-voltage curves from the same cells as in $A$ and $B$, respectively. The leak current is indicated by the dashed line fitted to the data between -60 and $-100 \mathrm{mV}$. Barium current in tall neural cells was larger than that in short abneural cells.

in neural (tall) cells at $2.0 \mathrm{~mm}$. The relationship between average peak barium current and average release area is shown in Figure $10 \mathrm{~B}$. These data have been fitted with a power relationship with an exponent of 0.74 , suggesting that barium currents through calcium channels are proportional to release site area in these hair cells. An exponent of $<1$ implies that current density at the release site is not constant but rather falls as release area rises.

\section{DISCUSSION}

Calcium channel number was correlated with presynaptic structures in hair cells of the chick's basilar papilla. We found that tall (inner) hair cells consistently had larger barium currents and more PDBs than did short (outer) hair cells. Calcium channel number was not a function of PDB number, but instead was correlated with total release area, defined as the product of PDB number and size. These findings are consistent with the hypothesis that VGCCs in hair cells are expressed at sites of transmitter release and so increase in proportion to synaptic function. These observations also reaffirm the proposition that hair cells use dihydropyridine-sensitive L-type calcium channels to support transmitter release (Zidanic and Fuchs, 1995), thus departing from the pattern of non-L-type VGCCs used for transmitter release by neurons (for review, see Dunlap et al., 1995).

Several alternative explanations for this correlation have been considered. Cell size alone cannot generate these data because the cells with the smallest surface area ( $2 \mathrm{~mm}$ neural cells) have the largest barium currents (Table 1). Also, no evidence was found that "rundown" of VGCCs was significant within the duration of these measurements. Thus differences in barium current magnitude between cell types cannot be attributed to this process. A remaining concern is that some aspect of the experimental procedure, protease treatment for example, might have preferentially affected short abneural cells and thereby reduced their complement of VGCCs. This seems somewhat unlikely because short abneural cells have more of some types of channels than do tall neural cells (e.g., "A-type" $\mathrm{K}^{+}$channels and receptors and channels of the cholinergic synapse) (Murrow and Fuchs, 1990), 
A

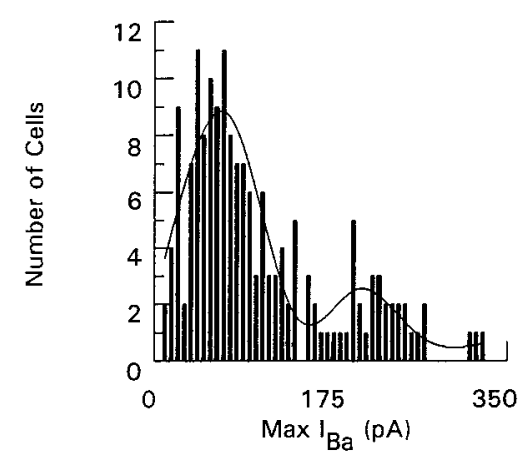

B

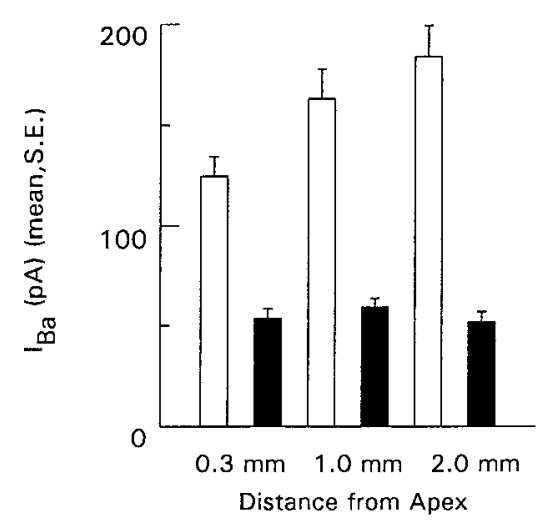

Figure 8. A, Distribution of peak barium current in 166 cells (from all positions). Steady-state current at the peak of the $I-V$ curve (between -10 and $10 \mathrm{mV}$ ) is shown. Smooth curve is the sum of two Gaussian distributions fit to the histogram with means at 70 and $205 \mathrm{pA}$. There appeared to be two classes of cells with respect to barium current amplitude. $B$, Mean values of barium current in each cochlear position $(+\mathrm{SE})$, with neural cell pools represented by open bars and abneural cells by filled bars. Each pool contained 29-31 cells, except those from $2.0 \mathrm{~mm}$ in which there were 22 neural cells and 25 abneural cells. Student's $t$ test showed that neural means were significantly different from abneural means for all regions. Also, neural cells at 0.3 were significantly different from neural cells at 1.0 and $2.0 \mathrm{~mm}$. Mean currents were not significantly different between neural cells at 1.0 and $2.0 \mathrm{~mm}(p=0.33)$.

but it remains a possibility. Finally, an important assumption of this study is that all chick cochlear hair cells express the same type of VGCC. Indeed, the voltage-sensitivity and activation kinetics of currents through these channels were shown to be identical in tall (neural) and short (abneural) hair cells (Zidanic and Fuchs, 1995). However, the pharmacology of VGCCs in short (abneural) hair cells has not been tested. It is possible then that a different, albeit functionally similar, voltage-gated calcium channel is expressed in short hair cells. Conotoxin-sensitive calcium currents have been observed in hair cells of frog semicircular canals (Prigioni et al., 1992), whereas single channel recordings from frog saccular hair cells revealed dihydropyridinesensitive and -insensitive channel types ( $\mathrm{Su}$ et al., 1995), supporting the possibility of N-type VGCCs in some hair cells. If present in abneural hair cells, non-L-type channels could be expressed extrasynaptically, that is, independent of release site organization.

The preferential expression of VGCCs by neural tall hair cells shown here may contribute to the gradient in acoustic thresholds observed in afferent fibers of the avian papilla (Gleich, 1989). Afferents innervating the neural-most hair cells have the lowest acoustic thresholds, consistent with the prediction that transmitter release onto afferents will be greatest from hair cells with greater numbers of calcium channels. Larger calcium currents also will enhance the sound-evoked depolarization, increasing the amplitude of the receptor potential itself. Afferents to abneural hair cells have been described less often, and when found have very high acoustic thresholds or may be specialized for the detection of ultrasound (Schermuly and Klinke, 1990). Generally, the function of abneural hair cells remains uncertain. Because they receive predominantly efferent innervation, they may serve a modulatory role analogous to that of outer hair cells in the mammalian cochlea. In any event, the present study suggests that the small number of VGCCs found in these hair cells may provide calcium for some function other than that of transmitter release.

Is the quantitative correlation between VGCCs and release area unique to chick neural hair cells? Some data exist permitting an extension of this analysis to hair cells in other nonmammalian species, in particular frog and turtle. To make these comparisons it is necessary to express the data as the number of calcium channels per total release area. The numbers of calcium channels per hair cell type ranges from approximately 100 in short hair cells to 341 in tall hair cells from the $2.0 \mathrm{~mm}$ region. [The single channel current in chick hair cells was estimated to be $0.54 \mathrm{pA}$ at $0 \mathrm{mV}$ in $20 \mathrm{~mm}$ barium based on single channel conductance from frog (Roberts et al., 1990) and turtle (Art et al., 1995) and corrected for increased barium permeability and curvature of the open channel current-voltage curve. The open probability was taken as 1 , because $0 \mathrm{mV}$ is near the peak of the activation curve for VGCCs in both tall and short hair cells (Zidanic and Fuchs, 1995)].

Roberts et al. (1990) estimated that frog saccular hair cells contain 1796 calcium channels. They have an average of 18.6 PDBs with an average diameter of $400 \mathrm{~nm}$. Therefore the total release area is $2.34 \mu \mathrm{m}^{2}$, calculated as for chick. Sneary (1988) mapped PDBs in turtle papillar hair cells and found a variation in number along the tonotopic axis. The diameter of PDBs in thin sections from turtle ranged from 250 to $500 \mathrm{~nm}$. Here we will use an estimate of $400 \mathrm{~nm}$, because this approximates the predicted diameter for a mean measurement of $375 \mathrm{~nm}$ (Elias and Hyde, 1983) and provides for consistency with the frog data. Extensive recordings and modeling studies of turtle hair cells provide information on the numbers of calcium channels in hair cells from the basilar papilla. Sneary's "midmembrane" hair cells (Sneary, 1988) contained 17.2 PDBs and should correspond to hair cells of $\sim 150 \mathrm{~Hz}$ (Art and Fettiplace, 1987), containing 1125 calcium channels $\left[N_{\mathrm{Ca}}=2\left(N_{\mathrm{KCa}}\right) ; N_{\mathrm{KCa}}=\right.$ $3.75 F_{0}$. Where $F_{0}$ is the tuning frequency, $N_{\mathrm{KCa}}$ is the number of calcium-activated potassium channels that determine the tuning frequency, and $N_{\mathrm{Ca}}$, the number of calcium channels, is twice the number of potassium channels ( $\mathrm{Wu}$ and Fettiplace, 1996)]. "Basal membrane" (high frequency) hair cells had 85.5 PDBs (with no difference in diameter reported) and should have tuning frequencies near the upper end of the turtle audible range. Here we have used $500 \mathrm{~Hz}$ because that is near the highest frequency actually observed for intracellular recordings from hair cells in situ (Crawford and Fettiplace, 1980). Thus a basal membrane hair cell would contain 3750 calcium channels by the above formulation.

Data from chick, frog, and turtle hair cells are plotted in Figure 


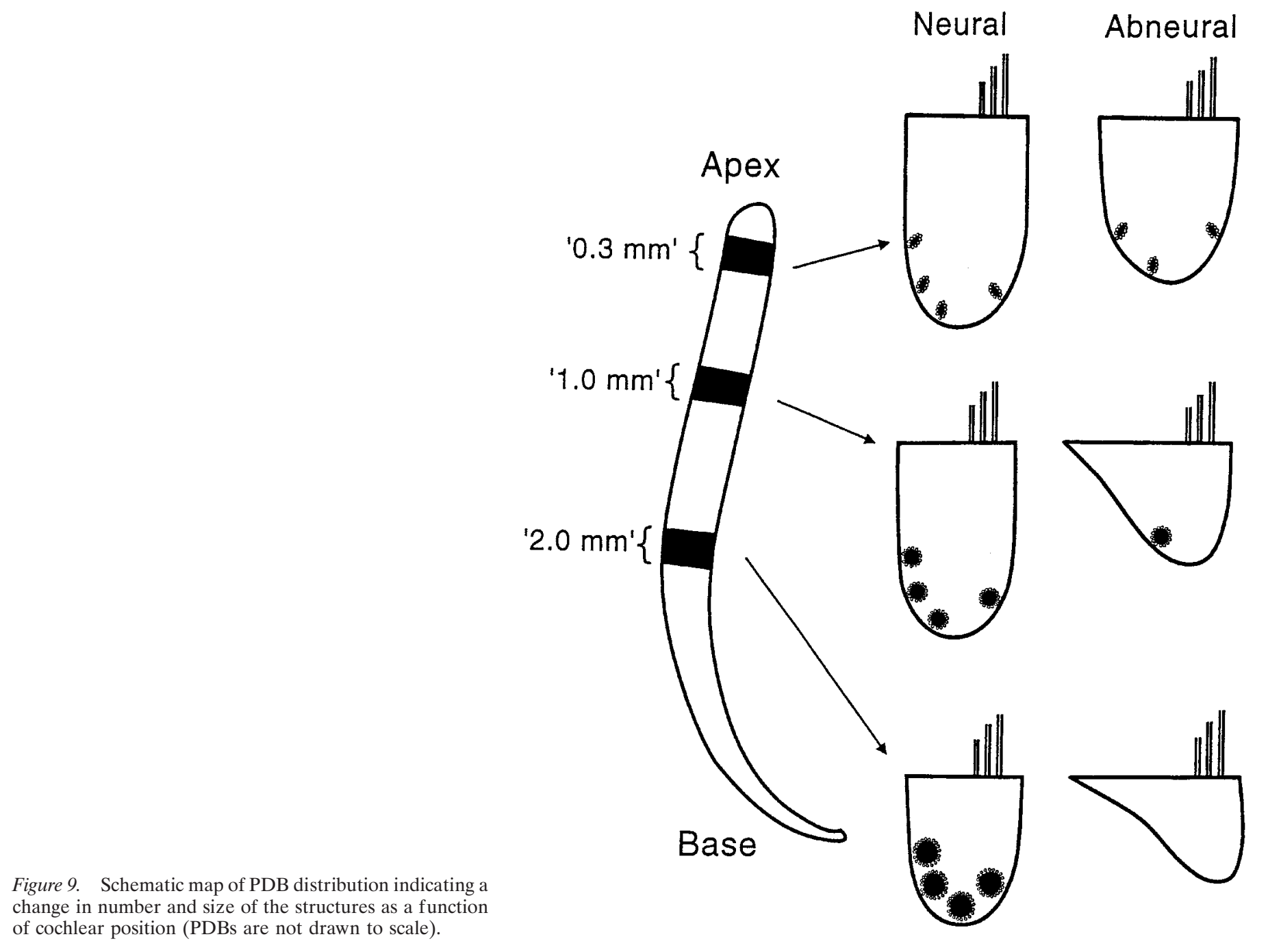

11. These have been fitted with a power function with an exponent of 0.70 . Four main conclusions can be drawn from this plot. First, total release site area and calcium channel number are correlated in hair cells from three different species. Second, the much smaller calcium currents observed in homeothermic chick hair cells compared with the larger currents in turtle and frog appear to be realistic and not attributable to metabolic trauma, given the smaller synaptic area in chick hair cells. Third, approximately the same number of release sites occur in chick (neural), frog, and midmembrane turtle hair cells, reinforcing the idea that larger release sites (those of turtle and frog) contain larger numbers of calcium channels than do smaller release sites (those of chick).

This correlation among hair cells of three vertebrate species supports the hypothesis that calcium channel number and presynaptic release area are causally related. This concept may apply to other channels as well. It is likely that largeconductance calcium-activated potassium channels are colocalized with VGCCs at release sites (Roberts et al., 1990; Issa and Hudspeth, 1994). Also, functionally and pharmacologically distinct voltage-gated potassium currents are found in tall neural (afferent) and short abneural (efferent) hair cells (Murrow, 1994), reminiscent of the differential expression of Shaker class $\mathrm{K}^{+}$channels in mammalian brain (Sheng et al., 1992), suggesting that most aspects of excitability may depend on the synaptic architecture of the hair cell.

A fourth and final point is that the proportionality between synaptic area and calcium channel number is $<1$, suggesting that calcium channel density falls as total release area rises. This implies that VGCCs are not packed at uniform density within the release site but rather within a more linear arrangement. Although various geometries could occur, it is worth noting that channel number increases linearly with the summed PDB perimeter for each cell type. VGCCs strung along the perimeter of the release site would occur at $\sim 20 \mathrm{~nm}$ intervals, the interchannel spacing suggested by atomic force microscopy of VGCCs in the chick ciliary calyx (Haydon et al., 1994). Thus perimetric or other linear arrays of VGCCs may be advantageous for excitationrelease coupling. Large intramembranous particles that might include calcium channels occur in rows at hair cell release sites (Roberts et al., 1990), as at neuromuscular junctions (e.g., Walrond and Reese, 1985).

The rapid coupling of calcium influx to transmitter release requires close localization of VGCCs to the release site (Adler et al., 1991) and so might limit the diameter (area) of circular release sites. Such constraints could be related to the activitydependent division of release sites observed at crayfish neuromuscular junction (Wojtowicz et al., 1994). Similarly, synaptic 

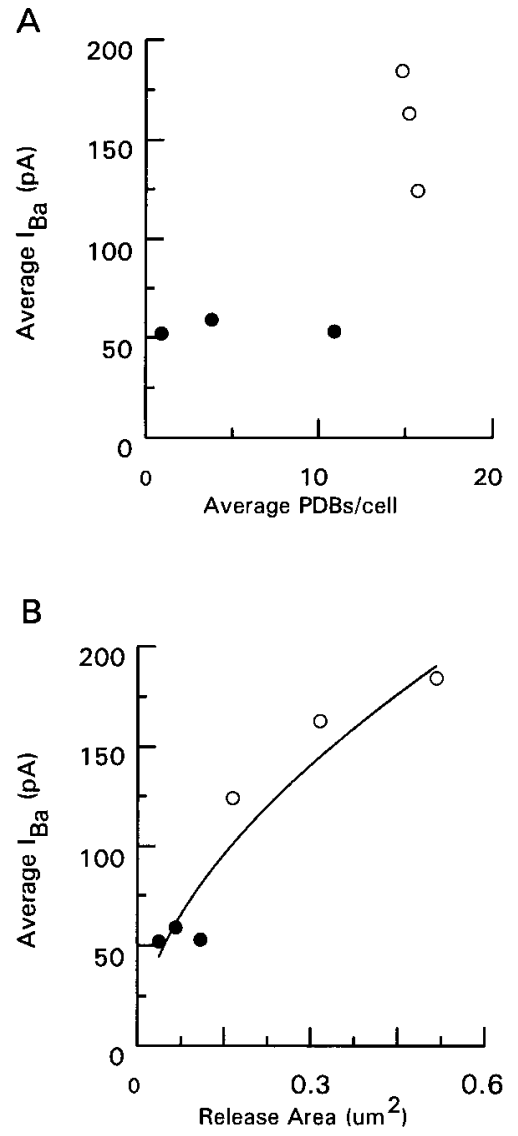

Figure 10. $A$, Mean peak barium current as a function of mean PDB number per cell. $B$, Mean peak barium current as a function of total release area (PDB number $\times$ cross-sectional area). Smooth curve drawn according to $y=420\left(x^{0.74}\right)$. Hair cells with larger release areas have larger currents. Open circles indicate neural (tall) hair cells; filled circles represent abneural (short) hair cells.

contacts of cells in the cochlear nucleus become smaller and more numerous as activity levels rise (Ryugo et al., 1996). Such morphological changes could reflect an effort to maximize the perimeter-to-area ratio as a general feature of release site

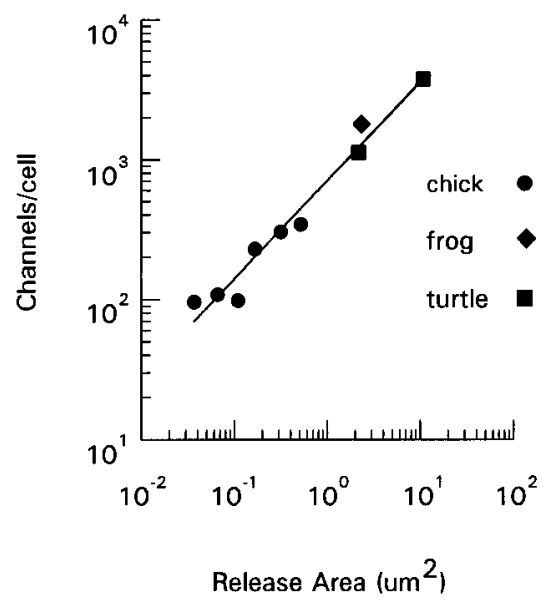

Figure 11. Calcium channels per cell plotted as a function of total release area in chick, frog, and turtle hair cells. Data from chick as in Figure $10 \mathrm{~B}$. Log-log fit according to $y=709\left(x^{0.70}\right)$. Hair cells with larger release areas have greater numbers of calcium channels. structure, thereby minimizing calcium influx through voltagegated channels for most efficient synaptic function.

\section{REFERENCES}

Adler EM, Augustine G, Duffy S, Charlton M (1991) Alien intracellular calcium chelators attenuate neurotransmitter release at the squid giant synapse. J Neurosci 11:1496-1507.

Art JJ, Fettiplace R (1987) Variation of membrane properties in hair cells isolated from the turtle cochlea. J Physiol (Lond) 385:207-242.

Art JJ, Fettiplace R, Wu Y-C (1993) The effects of low calcium on the voltage-dependent conductances involved in the tuning of turtle hair cells. J Physiol (Lond) 470:109-126.

Art JJ, Wu Y-C, Fettiplace R (1995) The calcium-activated potassium channels of turtle hair cells. J Gen Physiol 105:49-72.

Cohen MW, Jones O, Angelides, K (1991) Distribution of $\mathrm{Ca}^{2+}$ channels on frog motor nerve terminals revealed by fluorescent $\Omega$ conotoxin. J Neurosci 11:1032-1038.

Crawford AC, Fettiplace R (1980) The frequency selectivity of auditory nerve fibres and hair cells in the cochlea of the turtle. J Physiol (Lond) 306:79-125.

Dunlap K, Luebke J, Turner T (1995) Exocytotic $\mathrm{Ca}^{2+}$ channels in mammalian central neurons. Trends Neurosci 18:89-98.

Elias H, Hyde DM (1983) A guide to practical stereology. Basel, Switzerland: Karger.

Fischer F (1992) Quantitative analysis of the innervation pattern of the chicken basilar papilla. Hear Res 61:167-178.

Fuchs PA, Evans MG (1988) Voltage oscillations and ionic conductances in hair cells isolated from the alligator cochlea. J Comp Physiol 164:151-163.

Fuchs PA, Evans MG (1990) Potassium currents in hair cells isolated from the cochlea of the chick. J Physiol (Lond) 429:529-551.

Fuchs PA, Nagai T, Evans MG (1988) Electrical tuning in hair cells isolated from the chick cochlea. J Neurosci 8:2460-2467.

Fuchs PA, Evans MG, Murrow BW (1990) Calcium current in hair cells isolated from the cochlea of the chick. J Physiol (Lond) 429:553-568.

Gleich O (1989) Auditory primary afferents in the starling: correlation of function and morphology. Hear Res 37:255-268.

Haydon PG, Henderson E, Stanley EF (1994) Localization of individual calcium channels at the release face of a presynaptic nerve terminal. Neuron 13:1275-1280.

Hirokawa N (1978) The ultrastructure of the basilar papilla of the chick. J Comp Neurol 181:361-374.

Hudspeth AJ, Lewis RS (1988) Kinetic analysis of voltage- and iondependent conductances in saccular hair cells of the bull-frog Rana catesbeiana. J Physiol (Lond) 400:237-274.

Issa N, Hudspeth A (1994) Clustering of $\mathrm{Ca}^{2+}$ channels and $\mathrm{Ca}^{2+}$. activated $\mathrm{K}^{+}$channels at fluorescently labeled presynaptic active zones of hair cells. Proc Natl Acad Sci USA 91:7578-7582.

Kremer JR, Mastronarde DN, McIntosh JR (1996) Computer visualization of three-dimensional image data using IMOD. J Struct Biol 116:71-76.

Lewis RS, Hudspeth AJ (1983) Voltage and ion-dependent conductances in solitary vertebrate hair cells. Nature 304:538-541.

Murrow BW (1994) Position-dependent expression of potassium currents by chick cochlear hair cells. J Physiol (Lond) 480:247-259.

Murrow BW, Fuchs PA (1990) Preferential expression of transient potassium current, $I_{\mathrm{A}}$, by short hair cells of the chick's cochlea. Proc R Soc Lond [Biol] 242:189-195.

Ohmori H (1984) Studies of ionic currents in the isolated vestibular hair cell of the chick. J Physiol (Lond) 350:561-581.

Prigioni I, Masetto S, Russo G, Taglietti V (1992) Calcium currents in solitary hair cells isolated from frog crista ampullaris. J Vestib Res 2:31-39.

Roberts WM, Jacobs R, Hudspeth A (1990) Colocalization of ion channels involved in frequency selectivity and synaptic transmission at presynaptic active zones of hair cells. J Neurosci 10:3664-3684.

Robitaille R, Adler E, Charlton M (1990) Strategic location of calcium channels at release sites of frog neuromuscular synapses. Neuron 5:773-779.

Ryugo DK, Wu MM, Pongstaporn T (1996) Activity-related features of synapse morphology: a study of endbulbs of Held. J Comp Neurol 365:141-158.

Schermuly L, Klinke R (1990) Origin of infrasound sensitive neurones in the papilla basilaris of the pigeon: an HRP study. Hear Res 48:69-78. 
Sheng M, Tsaur M-L, Jan YN, Jan LY (1992) Subcellular segregation of two A-type $\mathrm{K}^{+}$channel proteins in rat central neurons. Neuron 9:271-284.

Sneary M (1988) Auditory receptor of the red-eared turtle: II. Afferent and efferent synapses and innervation patterns. J Comp Neurol 276:588-606.

Su Z-L, Jiang S, Gu R, Yang W (1995) Two types of calcium channels in bullfrog saccular hair cells. Hear Res 87:62-68.

Tanaka K, Smith C (1978) Structure of the chicken's inner ear: SEM and TEM study. Am J Anat 153:251-272.

Tucker T, Fettiplace R (1995) Confocal imaging of calcium microdomains and calcium extrusion in turtle hair cells. Neuron 15:1323-1335.

Walrond JP, Reese TS (1985) Structure of axon terminals and active zones at synapses on lizard twitch and tonic muscle fibers. J Neurosci 5:1118-1131.

Wojtowicz JM, Marin L, Atwood HL (1994) Activity-induced changes in synaptic release sites at the crayfish neuromuscular junction. J Neurosci 14:3688-3703.

Wu Y-C, Fettiplace R (1996) A developmental model for generating frequency maps in the reptilian and avian cochleas. Biophys $\mathbf{J}$ 70:2557-2570.

Zidanic M, Fuchs PA (1995) Kinetic analysis of barium currents in chick cochlear hair cells. Biophys J 68:1323-1336.

Zidanic M, Fuchs PA (1996) Efferent synaptic endings in the chick's cochlea revealed by synapsin immunohistochemistry. Aud Neurosci $2: 347-362$. 